\title{
Matteo Compareti. « Ancient Iranian Decorative Textiles: New Evidence from Archaeological Investigations and Private Collections »
}

\section{Alexandra Van Puyvelde}

\section{(2) OpenEdition Journals}

Electronic version

URL: http://journals.openedition.org/abstractairanica/42713

DOI: $10.4000 /$ abstractairanica. 42713

ISBN: 1961-960X

ISSN: 1961-960X

Publisher:

CNRS (UMR 7528 Mondes iraniens et indiens), Éditions de l'IFRI

\section{Electronic reference}

Alexandra Van Puyvelde, « Matteo Compareti. « Ancient Iranian Decorative Textiles: New Evidence from Archaeological Investigations and Private Collections » », Abstracta Iranica [Online], Volume 37-38-39 | 2018, document 7, Online since 10 March 2018, connection on 02 October 2020. URL http://journals.openedition.org/abstractairanica/42713; DOI : https://doi.org/10.4000/ abstractairanica.42713

This text was automatically generated on 2 October 2020 .

Tous droits réservés 


\title{
Matteo Compareti. « Ancient Iranian Decorative Textiles: New Evidence from Archaeological Investigations and Private Collections »
}

\author{
Alexandra Van Puyvelde
}

\section{REFERENCES}

Matteo Compareti. « Ancient Iranian Decorative Textiles: New Evidence from Archaeological Investigations and Private Collections ». The Silk Road, vol. 13 (2015), p. 36-44.

1 The object of this study consists of two textile fragments, which are in a private collection and have a main decoration of pearl roundels containing respectively one single or two composite creatures with a dog's head, wings and a peacock's tail. Both fabrics are radio-carbon dated, respectively to the $9^{\text {th }}-10^{\text {th }}$ century and to the beginning of the $8^{\text {th }}$ - end of the $9^{\text {th }}$ century.

2 M. Comparetti elaborates on the iconography of the composite winged creature, which is often referred to as simurgh in Farsi (senmurv in Pahlavi, saena maregha in Avestan). According to the author, the identification of this composite animal as the simurgh of Iranian mythology cannot be justified, as the simurgh is always represented as a bird (for example in pre-Islamic Sogdian paintings or in Iranian book illustrations of Islamic periods), just as it was described in written sources. Therefore, he puts forward the term "pseudo-simurgh" to be used for this fantastic creature. 
3 The author relates both fabrics on stylistic base to the group of the so-called "Zandaniji silks" and proposes to situate them in Sogdiana after Islamization, more precisely in the Samanid emirates during the $9^{\text {th }}-10^{\text {th }}$ centuries.

4 If Compareti's research could be completed with analyzes of the weaving technology and the dies and also with a study of the other decorative motifs on the textiles (so not only the medallions with the fantastic creatures), more decisive answers could be given concerning the origin of both textiles.

\section{AUTHORS}

\section{ALEXANDRA VAN PUYVELDE}

Royal Museums of Art \& History, Bruxelles 